\title{
Penal Mediation: Alternative Means of Criminal Law Enforcement Under Construction of Transcendental Law
}

\author{
Ikhsan Alfarisi ${ }^{1}$, Deni Handani ${ }^{2}$, Burhanuddin $^{3}$ \\ \{Ikhsanalfarisi19@gmail.com ${ }^{1}$, Denihandani91@gmail.com², fariburhanuddin@gmail.com ${ }^{3}$ \}
}

Department of State Administration, School of Administrative Sciences Setih Setio, Indonesia

\begin{abstract}
The construction of the modern state of the law with Positivism as the foundation of the present state of Indonesia's punishment has existed since Dutch colonialism. The in-depth foundation of legal positivism is not balanced with the legal culture as the glue the construction of a state on positivism law. Its comes from the style of civil law system / European continental - inconsistencies in criminal law enforcement, criminal law used as premium medium from the outside the criminal law field and the inclusion of state intervention (public law) that is too deep into private law (citizens) can be categorized as indicators of the shaky construction the state of modern law in Indonesia. The transcendental law emphasizes the reflection/contemplation activities between science and value; rational modern thought is supposed to deprive substantial things that are hidden values in the human conscience of religion, ethics, and morality. Discourse between value and science is epistemology dimension of transcendental law. Penal Mediation as a third way in criminal law enforcement is a new idea in solving the case of criminal law although in practice it has been applied for a long time. Therefore, this paper aims to open the ontology of penal mediation about transcendental law which is a new discourse in Indonesian law. The hypothesis is that Penal Mediation accommodates and places human as a cogito, free subject and is in the interactionist pattern of space and time of dynamic existence. The relevance of penal mediation as an alternative means of settling criminal cases within the framework of transcendental law is on it is beyond and fluidity so that the method of study here will use the discourse method.
\end{abstract}

Keywords: criminal law enforcement, penal mediation, transcendental law.

\section{Introduction}

The construction of the modern state of the law with Positivism as the foundation of the present state of Indonesia has existed since Dutch colonialism. The concept of the rule of law 
itself was well known long before World War II, along with the struggle against the Absolute power in seventeenth-century as known the absolute power of Kings in most Western European countries. However, the term rechtsstaat itself first used by Rudolf Von Gneist (1816-1895) Professor in Berlin, Germany, in his book "das Englische verwatungerechte" for the stereotype of the reign of the British State in the 19th century [1].

The State of Law (Rechtsstaat) is a State which aims to carry out legal order, namely the order which is generally based on the law contained in the people. The law states maintain lawful order not to be disturbed and keep all proceed according to the law [2].

Furthermore, foundation of legal positivism is not balanced with the legal culture as the glue the construction of a state of positivism law that comes from the style of civil law system / continental European. Consequently, inconsistencies in criminal law enforcement, criminal law serve as primum remedium of law outside of criminal law field and the inclusion of state intervention (public law) too deep into private law (citizens) as well as the penitentiary institution far from the purpose its presented can be categorized as indicators of the shaky construction of the state of modern law in Indonesia.

The transcendental law emphasizes reflection activities between science and value; rational modern thought is supposed to deprive substantial things that are hidden values in the human conscience of religion, ethics, and morality. Ontologically transcendental paradigm reaches religion, ethics, and morality because Positivism in practical level is considered to reduce the idealistic value that causes a crisis in meaning.

From the above explanation, some of the issues discussed are:

1. What is the concept of penal mediation in criminal law enforcement?

2. What is the relation of penal mediation in the construction of transcendental law?

\section{Methods}

This paper uses a literature study. The study focuses on the themes and discourses that exist in penal mediation in the construction of transcendental law. Therefore, the analysis in this study uses discourse analysis approach. The study method with Discourse Analysis can be described as a study of the discourse that develops in society. Discourse analysis itself was developed by structuralists and post-structuralists as a study of the structure of reality. This implies that reality is the formation of a developing discourse. This text becomes a medium of understanding of language and reality and vice versa [3]. In other words, the starting point is the text. 


\section{Analysis and Discussion}

\subsection{Penal Mediation in Criminal Law Enforcement}

Penal policy or criminal law policy itself is part of criminal policy or policy in the prevention of crime. So it can be said the penal policy is a crime prevention policy with criminal law [4]. The criminal policy itself is essentially an integral part of social protection effort (social defense policy) and efforts to achieve social welfare (social welfare).

The accommodating of penal mediation opens the way for flexibility in sorting and placing a case proportionally without reducing the national criminal law authority. Medio 1994 in UAE, the criminal case of a female laborer from the Philippines, Sarah Balabagan who murdered her employer Mohammed Al-Baloushi became the international lips of the world, because after receiving permission from the victim's family with compensation, the defendant escaped from the death penalty by paying 150,000 dirhams $(\$ 40,000)$ through UAE Islamic Court verdict.

Another comparison, still in 1994, the Gacaca trial in Rwanda became an precedent on international eye that the synergy between national criminal law and local law could solve cases appropriately with hundreds or even thousands of perpetrators because the genocide case in Rwanda between Hutu tribe and Tutsi tribe, thousands of people associated with the tribal and its leaders, were punished through grass root justice: Rwanda GacacaCourt, compared with the settlement of cases of Serious Human Rights violations Tanjung Priok, based on findings Elsam concluded full of power politics, select feathers and lead to free decision of the defendant.

Mediation penal in the practical criminal field should have a decent place because of its accordance with the mindset of the Indonesian nation. Even in various advanced countries, penal mediation has been formulated both in Formal Criminal Law (ex:Netherlands) and the Material Criminal Law (ex:Germany).

Penal mediation can be classified into three basic forms: First, Community Based means penal mediation based on community, that has a system of social order values such as mediation of penal in indigenous peoples. Second, Restore / Offender-Victim Based means penal mediation oriented to the return of losing or individual interest, especially the victim who must be returned to the previous situation, such as child/juvenile delinquency, traffic accident, and domestic violence. Third, Informal Based means other mediation penal which is possible or advantageous when using penal mediation rather than the criminal justice systems, like a fraud in banking and others.

The general principles of penal mediation are informal, volunteer, participative, impartial, restorative and enforceable at every stage of the criminal justice system. Penal mediation may be applicable in every criminal case, but in order to avoid abuse of its presence and the 
limitations of its structure, penal mediation should be formulated in a limited and specialized manner. Limitation means what matters can be pursued by penal mediation mechanism, specifically to whom any penal mediation may be applied.

\subsection{Penal Mediation Under Transcendental Law Construction}

Transcendental law is a discourse in law that developed in Surakarta Colleges especially at Muhammadiyah University of Surakarta; this discourse is the development of Progressive Law thought developed by Satjipto Rahardjo in Diponegoro University, Semarang. This thought put the God spot as the determining factor of law enforcement and human beings as the focus that allows law enforcer is breaking the rule by substantive justice.

Danah Zohar and Ian Marshall in "Spiritual Intelligence, The Ultimate Intelligence", criticize the failure of western civilization by introducing spiritual thinking using the spiritual quotient approach, which will be obtained by the ultimate intelligence, how to tackle the lines of formalism (existing rule) and transcendental, so that new ideas can be obtained that approached the ultimate truth. Humans need spiritual quotient because in western society there has been degradation of the meaning of life in the modern world (the crisis of meaning). The spiritual quotient is a tool for humans to be able to build new perspectives in life, able to find wide horizons in a narrow world and can feel the presence of God without meeting God. Spiritual Quotient can be used to evoke hidden human potentials, make people more creative and able to overcome essential problems. Spiritual Quotient is also a clue when humans are between order and chaos, giving intuition about meaning and value [5].

On the transcendental legal science perspective, the science of law is not only based on truth on the level of haqq al-yakin, which is collected in the Al-Qur'an and Hadith but also based on the truth obtained by human potential ability through reflection, reasoning and discourse developed in society. Humans dig, cultivate and formulate science with the aim not only for science but also for policy, the welfare of the wider community, with the pleasure, and the love of God [6].

The science of transcendental law is rooted in the will of God to his creatures sent down through His prophets and apostles, the mualim and aulia who are always istiqomah and cling to the divine line (sunnahtullah). Sunnahtullah is the basis of the philosophy of natural law is translated through His verses both written (Al-Qur'an and Hadith) as well as the translated in the universe and the reality of life. The science of transcendental law is aimed at guiding human life to the happiness of the world and the hereafter [7].

The science of transcendental law can only be understood by a holistic approach which sees man and his life in the form of a whole, not merely material but ruhaniyah (inmaterial). The science of transcendental law cannot be separated between physical (formal) bodies and transcendental values. Justification of transcendental law pursued is for justice based on the 
truth of the power of God, the Essence of the Almighty, the determinant of life and human life. The science of transcendental law is oriented towards the benefit of man as a manifestation of compassion for his creatures [8].

Penal mediation as a conflict resolution mechanism in the construction of transcendental law lies in its fluidity as well as it is beyond as an alternative means of law enforcement as well as a social control mechanism. It is certainly very relevant to the need for law enforcement today which is an integral part of social policy because it tends to alienate material/substantive justice. Ontologically, transcendental law emphasizes reflection activity between science and value. Discourse between value and science is the dimension of the epistemology of transcendental law.

\section{Conclusion}

First, Mediation penal should have a place within the framework of national law enforcement because it is by the mind of the nation of Indonesia. Penal mediation can be classified into Community Based, Restore / Offender-Victim Based, Informal Based. The general principles of penal mediation are informal, volunteer, participative, impartial, restorative and enforceable at every stage of the criminal justice system and used on limitative and specialized manner. Second, Penal mediation as a conflict resolution mechanism in the construction of transcendental law lies in its fluidity as well as its beyond as an alternative means of law enforcement as well as a social control mechanism. This is certainly very relevant to the need for law enforcement today which is an integral part of social policy because it tends to alienate material/substantive justice. Ontologically, transcendental law emphasizes reflection activity between science and value. Discourse between value and science is the dimension of the epistemology of transcendental law.

\section{References}

References

[1] FH and UI Community Science in Mukhtie Fadjar, Type of Law Country, Malang: Bayu Media, 2005. p. 10

[2] W. Van Hoeve in Mukhtie Fadjar, Type of Law Country, Malang: Bayu Media, 2005, p. 5

[3] Marianne Jorgensen and Louise Phillips. Discourse Analysis as Theory And Methods. London: Sage Publication. 2002. p. 21 
[4] Barda Nawawi Arief, Culmination of Criminal Law Policy, Bandung: Citra Aditya Bakti, 2002. p. 23

[5] Danah Zohar and Ian Marshall in Absori, Epistemology of Transcendental Law and its Implementation in Development of Doctoral Program of Law Science, Proceedings of the Development of Epistemology of Law Science, ISBN 978-60272446-0-3, Surakarta: UMS, April 11, 2015. p.37

[6] Danah Zohar and Ian Marshall in Absori, Epistemology of Transcendental Law and its Implementation in Development of Doctoral Program of Law Science, Proceedings of the Development of Epistemology of Law Science, ISBN 978-60272446-0-3, Surakarta: UMS, April 11, 2015. p.45

[7] Danah Zohar and Ian Marshall in Absori, Epistemology of Transcendental Law and its Implementation in Development of Doctoral Program of Law Science, Proceedings of the Development of Epistemology of Law Science, ISBN 978-60272446-0-3, Surakarta: UMS, April 11, 2015. p. 37

[8] Danah Zohar and Ian Marshall in Absori, Epistemology of Transcendental Law and its Implementation in Development of Doctoral Program of Law Science, Proceedings of the Development of Epistemology of Law Science, ISBN 978-60272446-0-3, Surakarta: UMS, April 11, 2015. p. 37 